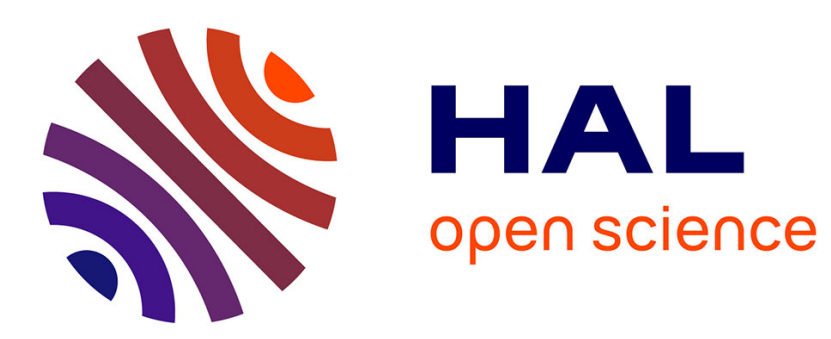

\title{
Role of injured endothelial cells in the recruitment of human pulp cells
}

\author{
Sylvie Mathieu, Assou El-Battari, Jacques Dejou, Imad About
}

\section{To cite this version:}

Sylvie Mathieu, Assou El-Battari, Jacques Dejou, Imad About. Role of injured endothelial cells in the recruitment of human pulp cells. Archives of Oral Biology, 2004, 50 (2), pp.109-113. 10.1016/j.archoralbio.2004.11.008 . hal-03552459

\section{HAL Id: hal-03552459 \\ https://hal.science/hal-03552459}

Submitted on 2 Feb 2022

HAL is a multi-disciplinary open access archive for the deposit and dissemination of scientific research documents, whether they are published or not. The documents may come from teaching and research institutions in France or abroad, or from public or private research centers.
L'archive ouverte pluridisciplinaire HAL, est destinée au dépôt et à la diffusion de documents scientifiques de niveau recherche, publiés ou non, émanant des établissements d'enseignement et de recherche français ou étrangers, des laboratoires publics ou privés. 


\title{
Role of injured endothelial cells in the recruitment of human pulp cells
}

\author{
Sylvie Mathieu ${ }^{\mathrm{b}}$, Assou El-Battari ${ }^{\mathrm{b}}$, Jacques Dejou ${ }^{\mathrm{a}}$, Imad About ${ }^{\mathrm{a}, *}$
}

aLaboratoire IMEB - ERT 30, Faculté d'Odontologie, Université de la Méditerranée, 27 Boulevard Jean Moulin, 13385 Marseille Cedex 05, France

'INSERM U559, Faculté de Médecine, Marseille, France

Accepted 2 November 2004

\section{KEYWORDS}

Human pulp stem cells;

Migration;

Endothelial cells;

Injury

\begin{abstract}
Summary In restorative dentistry, deep cavity preparation may lead to partial destruction of the odontoblastic layer. However, newly formed odontoblast-like cells can replace the necrotic odontoblasts and secrete a reparative dentine matrix. While growth factors such as transforming growth factor $\beta 1$ (TGF $\beta 1$ ) and bone morphogenetic proteins (BMP-2 and BMP-4) seem to be involved in the proliferation and differentiation of pulp cells, little is known about the migration of the newly proliferating stem cells to the injury site. Our hypothesis was that endothelial cell injury may be involved in directing these cells towards the injury site.

For this study, human pulp fibroblasts and L929 cells were fluorescence-labeled by transduction with the Enhanced Green Fluorescent Protein (EGFP). Similarly, human umbilical vein endothelial cells (HUVEC) were labeled with the Discosoma Red Fluorescent Protein-2 (DsRed2). Cell migration was then studied in an insert cell culture system. The HUVEC cells were cultured in the lower compartment while the human pulp fibroblasts or L929 were in the upper compartment.

After artificial injury to the HUVEC cells, only human pulp fibroblasts migrated to the lower compartment. At early time periods ( 4 days), migrating cells were randomly localized on the HUVEC layer. However, after 14 and 20 days, they were perfectly aligned along the injury site. In the absence of injury, no migration was observed.

These results suggest that, the endothelial injury is involved in the recruitment of odontoblast-like cells at the injury site.
\end{abstract}

\section{Introduction}

In pathological conditions, such as mild carious dentine lesions, odontoblastic activity is stimulated to elaborate reactionary dentine. Severe lesions or deep cavity preparation may lead to local odontoblast death. However, newly formed cells attracted 
to the injury site, can differentiate into odontoblast-like cells and secrete a reparative dentine matrix. Several lines of evidence suggest the presence of progenitor or postnatal stem cells in the pulp capable of differentiation into odontoblast-like cells and secretion of reparative dentine in vitro. ${ }^{1}$ After transplantation into immunocompromised mice, a dentine-like structure lined with odontoblasts and surrounding a pulp like interstitial tissue was obtained. ${ }^{2}$

Growth factors such as transforming growth factors (TGF $\beta s$ ), bone morphogenetic proteins (BMPs) fibroblast growth factors (FGFs) and insulin growth factors (IGFs) are secreted by functional odontoblasts and pulp fibroblasts, and are sequestered in the dentine matrix which can be considered as a reservoir of growth factors. ${ }^{3,4}$ After carious injury, these factors are released as the dentine is demineralised with the acidic environment resulting from plaque bacterial metabolism. ${ }^{5,6}$ Among these growth factors, TGF $\beta 1$ and BMP- 2 and BMP- 4 seem to be involved in the proliferation and differentiation of pulp cells, thus providing chemotactic signals to recruit progenitor pulp cells at the injury site and to initiate tissue repair. ${ }^{7,8}$

On the other hand, after surgical pulp amputation, healing can occur with hard tissue formation in germ-free animals independently of a local acidic environment. ${ }^{9,10}$ This indicates the high healing potential of the dental pulp. However, under these conditions, very little is known about the migration and recruitment of the newly proliferating progenitor cells to the injury site. Moreover, pulp injury is likely to also involve the blood vessels within this organ. It is well established that injured endothelial cells release signaling molecules to initiate inflammatory reactions and the healing process. $^{7}$ Our hypothesis was that endothelial cells injury may also be involved in directing progenitor/stem cells towards the injury site.

\section{Methods}

\section{Materials}

The pEGFP-N1 and pDsRed2-N1 vectors were from Clonetech (Palo Alto, CA, USA). These plasmids carry the Enhanced Green Fluorescent Protein (EGFP) ${ }^{11}$ and the Discosoma Red Fluorescent Protein (DsRed2), ${ }^{12}$ respectively.

Culture media and reagents were purchased from BioWhittaker (Gagny, France). Chemicals were obtained from Sigma Chemicals Corporation (St. Louis, MO) unless otherwise stated.
The pL1-EGFP and pL1-DsRed2 constructs were prepared as described in Mathieu et al. ${ }^{13}$ Human pulp fibroblasts prepared from immature third molars $^{1}$ and the L929 fibroblastic cell line (NCTC, Paisley, UK) were fluorescence-labeled by transduction with the Enhanced Green Fluorescent Protein according to Naldini et al. ${ }^{14}$ as modified by Mathieu et al. ${ }^{13}$ Similarly, human umbilical vein endothelial cells (HUVEC) (Cambrex Bioscience, MD, USA) were fluorescence-labeled by transduction with the Discosoma Red Fluorescent Protein-2. The insert cell culture system (Corning, NY, USA) containing a polycarbonate membrane ( $8 \mu$ pore size) was used to study cell migration in response to injury. In the Insert culture system, the DsRed2-labeled HUVEC cells were cultured in EBM-2 medium (Cambrex Bioscience, MD, USA) in the lower compartment while the EGFP-labeled human pulp fibroblasts or L929 were cultured in DMEM medium $(4.5 \mathrm{~g} / \mathrm{L}$ glucose) in the upper compartment.

When the cells reached confluence, both cell types were incubated in the EBM-2 medium and mounted in the insert culture system. Injuries were performed mechanically with sterile scalpels on the HUVEC cells in the lower compartment. The scalpels

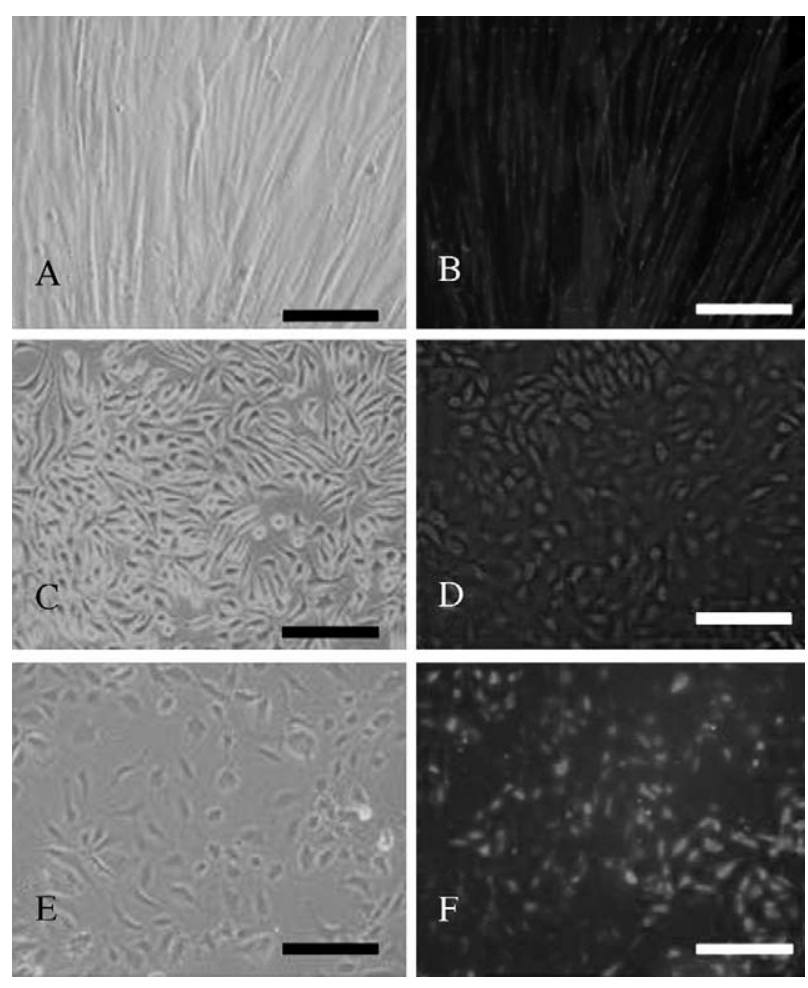

Figure 1 Fluorescence transduction of the cells: pulp fibroblasts and L929 fibroblastic cell were EGFP-labeled. Human endothelial HUVEC cells were DsRed2-labeled. Micrographs represent the phase contrast and fluorescence labeling of pulp fibroblasts (A and B), L929 (C and D) and HUVEC cells (E and F). Scale bars: $100 \mu \mathrm{m}$. 
were used to induce injury manually by making two continuous straight line incisions to disrupt the HUVEC monolayer. Migration from the upper to the lower compartment was controlled every day under an inverted fluorescence microscope (Carl Zeiss, Gottingen, Germany).

\section{Results}

After transduction of human pulp fibroblasts (Fig. 1A and B) and L929 cells (Fig. 1C and D), cells were successfully infected and exhibited a homogenous green fluorescence. Similarly, HUVEC cells were successfully infected and exhibited a homogenous red fluorescence (Fig. 1E and F).

After artificial injury to the HUVEC cells, human pulp fibroblasts migrated to the lower compartment. Early in their migration (4 days), they were randomly localized on the HUVEC cells (Fig. 2A). After 7 days, although some migrating cells were visible at the injury site, most were still randomly localized on the HUVEC cells, (Fig. 2B). At 14 days, most of the migrating cells were aligned along the injury site (Fig. $2 \mathrm{C}$ ). The number of cells around the injury site increased after 20 days (Fig. 2D). In the absence of injury, no migration was observed. When the same type of injury was performed but with the L929 cells replacing the human pulp fibroblasts in the upper compartment, no migration was observed (data not shown).

\section{Discussion}

Our earlier studies have shown that third molar derived pulp cells have the potential to differentiate into odontoblast-like cells. When cultured with $\beta$-glycerophoshate, they secrete an extracellular matrix deposit which progressively forms nodules of mineralized material. Fourier transform infrared spectroscopic analysis showed that this deposition
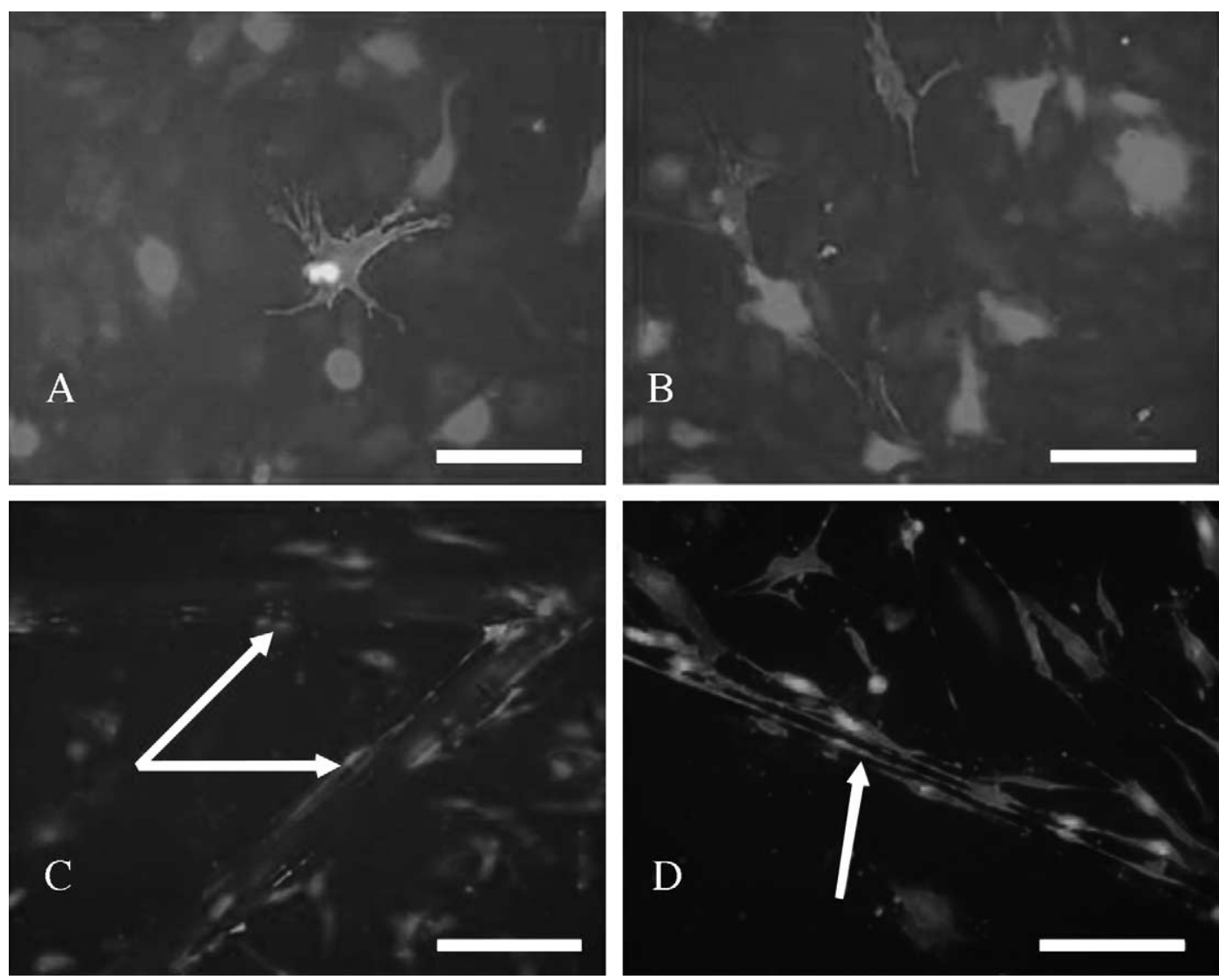

Figure 2 Migration of human pulp fibroblasts. In the Insert culture system, the HUVEC cells were cultured in the lower compartment while human pulp fibroblasts or $\mathrm{L} 929$ were cultured in the upper compartment. After injury, pulp fibroblasts migrated from the upper to the lower compartment. At 4 days, the migrating cells were randomly localized on the HUVEC cells (A). At 7 days, although some migrating cells were visible at the injury site the majority were still randomly localized on the HUVEC cells (B). At 14 days, most of the migrating cells were aligned along the injury site (C). The number of cells around the injury site increased after 20 days (D). Arrows indicate the injury sites. Scale bars in $(A$ and $B): 50 \mu \mathrm{m} ;(C$ and D): $100 \mu \mathrm{m}$. 
has a similar mineral composition to that of dentine and differs from that of enamel and alveolar bone. ${ }^{1}$ After differentiation, these cells respond to BMP-4 and express the specific odontoblast molecular markers such as nestin and dentin sialoprotein. ${ }^{15,16}$ Consequently, these cells were conveniently used as progenitor stem cells in the present study.

Reparative dentine synthesis is a complex biological process. It requires the presence of progenitor cells, their proliferation, migration, recruitment and activation at the injury site to differentiate into odontoblast-like cells secreting the hard protective reparative dentine. Growth factors, such as TGFBs and BMPs are key regulators of reactionary and reparative dentinogenesis. TGFB1 up-regulation at the injury site plays an important role in the healing process. ${ }^{8}$ Moreover, the addition of various growth factors such as TGFBs, IGFs, FGFs and crude BMP to the culture medium of pulp cells can stimulate DNA synthesis and glycoprotein synthesis. However, the dental pulp has a naturally high inherent regenerative potential. This is demonstrated by the fact that, after surgical pulp amputation, healing was observed in germ free animals without any application of growth factors. ${ }^{9,10}$

The dental pulp is a highly vascularized tissue and pulp cavities preparations result in a subsequent injury of pulp tissue including the blood vessels. It is well recognized that injured endothelial cells release chemotactic factors and signaling molecules to initiate the inflammatory process, and express adhesion molecules ${ }^{17}$ necessary for the recruitment of inflammatory and progenitor cells for initiating the healing process. ${ }^{7}$ For example, FGF2 release from the dentine matrix or endothelial cells is involved in angiogenesis and may act as mitogen for pulp progenitor cells. ${ }^{18}$

The present study adds to our understanding of reparative dentinogenesis in that pulp cells can migrate in response to endothelial cell injury. The migration observed here cannot be due to a simple passive diffusion of the pulp cells through the $8 \mu \mathrm{m}$ pore size membrane as the L929 fibroblasts, which are smaller in size than the pulp cells, did not respond to the endothelial cell injury. Moreover, the migrating cells, which are randomly localized on the endothelial cells at the beginning of their migration, become strikingly reorganized around the injury site.

Our results may help us to understand the successful production of tubular dentine after transplantation of progenitor mesenchymal cells to highly vascularized tissues. ${ }^{2,19}$ This may be due, at least in part, to release of signaling molecules from injured endothelial cells for the recruitment of the transplanted cells together with the fact that, pulp cells express growth factors necessary for their differentiation. ${ }^{6}$

Migration and recruitment at injury sites require at least two types of signals: expression of adhesion molecules on endothelial cells and release of chemotactic factors into the culture medium. These are currently under investigation.

In conclusion, these results suggest that injured endothelial cells are involved in the recruitment of the odontoblast-like cells at the injury site. In restorative dentistry, these results contribute to a better understanding of the mechanisms involved in the migration and recruitment of newly proliferating cells after pulp injuries.

\section{References}

1. About I, Bottero MJ, De Denato P, Camps J, Franquin JC, Mitsiadis TA. Human dentin production in vitro. Exp Cell Res 2000;258:33-41.

2. Gronthos S, Mankani M, Brahim J, Robey PG, Shi S. Postnatal human dental pulp stem cells (DPSCs) in vitro and in vivo. PNAS 2000;97:13625-30.

3. Finkelman RD, Mohan S, Jennings JC, Taylor AK, Jepsen S, Baylink DJ. Quantitation of growth factors IGF-I, SGF/IGF-II and TGF-beta in human dentin. $J$ Bone Miner Res 1990;5:717-22.

4. Ruch JV, Lesot $\mathrm{H}$, Bègue-Kirn C. Odontoblast differentiation. Int J Dev Biol 1995;39:51-68.

5. Goldberg M, Smith AJ. Cells and extracellular matrices of dentin and pulp: a biological basis for repair and tissue engineering. Crit Rev Oral Biol Med 2004;15:13-27.

6. Tziafas D, Smith AJ, Lesot $H$. Designing new treatment strategies in vital pulp therapy. J Dent 2000;28:77-92.

7. Martin P. Wound healing: aiming for perfect skin regeneration. Science 1997;276:75-81.

8. D'Souza RN, Cavender A, Sood R, Tarnuzzer R, Dichinson D, Roberts A, et al. Dental abnormalities in mice lacking functional TGF( 1 gene suggests a role for TGF( 1 in biomineralization. Int J Dev Biol 1998;23:119-31.

9. Tsuji T, Takel K, Inoue T, Shimono M, Yamamura T. An experimental study on wound healing of surgical exposed dental pulps in germ-free rats. Bull Tokyo Dent Coll 1987;28:35-8.

10. Inoue T, Shimono M. Repair dentinogenesis following transplantation into normal and germ-free animals. Proc Finn Dent Soc 1992;88(Suppl.):183-94.

11. Chalfie M, Tu Y, Euskirchen G, Ward WW, Prasher DC. Green fluorescent protein as a marker for gene expression. Science 1994;11(263):802-5.

12. Matz MV, Fradkov AF, Labas YA, Savitsky AP, Zaraisky AG, Markelov ML, et al. Fluorescent proteins from nonbioluminescent Anthozoa species. Nat Biotechnol (17):1999;96973.

13. Mathieu S, Prorok M, Benoliel A-M, Uch R, Langlet C, Bongrand $P$, et al. Transgene expression of $((1,2)$-Fucosyltransferase-I (FUT1) in tumor cells selectively inhibits sialyl-lewis $x$ expression and binding to E-selectin without affecting synthesis of sialyl-lewis a or binding to P-selectin. Am J Pathol 2004;164(2):371-83. 
14. Naldini L, Blomer U, Gallay P, Ory D, Mulligan R, Gage FH, et al. In vivo gene delivery and stable transduction of nondividing cells by a lentiviral vector. Science 1996;272: 2637.

15. About I, Laurent-Maquin D, Lendahl U, Mitsiadis TA. Nestin expression in embryonic and adult human teeth under normal and pathological conditions. Am J Pathol 2000;157:287-95.

16. About I, Camps J, Mitsiadis TA, Butler W, Franquin J-C. Influence of resinous monomers on the differentiation in vitro of human pulp cells into odontoblasts. J Biomed Mater Res 2002;63:418-23.

17. Tedder TF, Steeber DA, Chen A, Engel P. The selectins: vascular adhesion molecules. FASEB J 1995;9:866-73.

18. Nugent MA, lozzo RV. Fibroblast growth factor-2. Int J Biochem Cell Biol 2000;32:115-20.

19. Braut A, Kollar EJ, Mina M. Analysis of the odontogenic and osteogenic potentials of dental pulp in vivo using a Col1a1-2.3-GFP transgene. Int J Dev Biol 2003;47: 281-92. 